\title{
Diversidade Cultural e Reconhecimento no Quadro de Políticas de Comunicação e Cultura no Brasil: desafios e perspectivas para concretização da Convenção da Unesco de 2005
}

Sayonara Leal'

\section{Resumo}

Este trabalho discute as políticas de comunicação e cultura no Brasil voltadas para radiodifusão, especialmente para a televisão e o audiovisual (cinema), em (des)compasso com o princípio de diversidade cultural, conforme a Convenção sobre a Proteção e a Promoção da Diversidade das Expressões Culturais da Unesco de 2005. Partimos de uma reflexão acerca da diversidade cultural como um problema construído no seio das sociedades multiculturais onde as demandas por reconhecimento operam a partir tanto da ideia de estima de si e respeito mútuo como daquela de justiça social, desembocando em lutas sociais permanentes dos membros das sociedades em suas rotinas de vida. Em seguida, vislumbramos o problema da diversidade cultural em cenários de monopólios dos meios de comunicação de largo alcance, como é o caso do Brasil, onde elementos de uma ética democrática como a liberdade de expressão encontram resistências em função da vigência de um modelo cultural hegemônico e reificante de produção e comercialização da cultura e da comunicação. Neste sentido, advogamos que a concretização dos princípios democratizantes do fazer cultural postos pela Convenção da Unesco de 2005 exige reformas em nosso marco legal para as Comunicações a partir do tripé cidadania, reconhecimento e diversidade cultural. A emergência de um espaço simbólico cosmopolita que envolva a visibilidade das narrativas e formas estéticas do universal e do particular que habitam a nossa diversidade cultural depende de amparo institucional e da rotinização do "reconhecimento normativo" como prática em nosso agir no mundo da vida.

Palavras-chave: Diversidade cultural. Reconhecimento. Políticas de comunicação e cultura no Brasil. Convenção da Unesco.

I Doutora em Sociologia. Professora Adjunta do Departamento de Sociologia da Universidade de Brasilia (UnB). Email: sayoleal@gmail.com 


\section{Introdução}

Este trabalho trata das políticas de comunicação e cultura no Brasil voltadas para radiodifusão, especialmente para a televisão e audiovisual (cinema), na perspectiva do princípio de diversidade cultural, conforme a Convenção sobre a Proteção e a Promoção da Diversidade das Expressôes Culturais da Unesco de 2005. A categoria de diversidade cultural aparece em documentos governamentais e na agenda dos movimentos sociais no Brasil como princípio norteador de políticas públicas de cultura, comunicação e educaçáo para o fortalecimento de práticas cidadãs. A Convenção da Unesco de 2005 nos leva a refletir sobre a importância de se pensar reformas em nosso marco legal para as Comunicaçóes a partir do tripé cidadania, reconhecimento e diversidade cultural. A diversidade cultural não pode ser realizada, em nossa perspectiva, sem a passagem obrigatória pelo reconhecimento de diferenças culturais, (in) visibilizadas pelos meios de comunicaçáo, porque essas caracterizam fortemente a composição da sociedade brasileira e nos remete ao princípio democrático da cidadania cultural.

No Brasil quando falamos de diversidade cultural referimo-nos às minorias étnicas, etárias, de gênero, mais precisamente, a cerca de 230 povos indígenas que falam cerca de 180 línguas (DUPPIN, 2008); 2.000 comunidades quilombolas; 6.329 comunidades urbanas (favelas), 6.914 comunidades ribeirinhas (BRASIL, 2012d); 291 comunidades ciganas, além de uma forte presença de orientaçóes sexuais não convencionais, representadas pelos movimentos LGBT. Diante desse quadro, falar de diversidade cultural no sentido das políticas de comunicação e cultura no Brasil é um desafio em termos de realização da Convenção da Unesco. Assim, gostaríamos de ressaltar três orientaçôes presentes na Convenção que são vistas como vias normativas para as políticas de fomento à diversidade cultural nos países signatários: apoio à produção de conteúdos culturais que retratem a diversidade estética, opinativa, étnica, religiosa do país; implementaçáo de meios e veiculação para distribuir essa produção e participaçáo social na gestão das políticas públicas de promoção de projetos e açóes de diversidade cultural. Daremos mais atenção, neste texto, a uma das barreiras mais efetiva que enfrentamos para realizar a Convenção da Unesco de 2005, no caso brasileiro, qual seja, o cumprimento 
do segundo princípio da Convenção, isto é, a distribuição de conteúdos produzidos na lógica da diversidade cultural, de forma que seja independente ou coordenada com a indústria cultural estabelecida no país.

Trata-se de dar visibilidade à diversidade de expressóes culturais nacionais, como também de outros países, como forma de existência pública destas, sendo, assim possível ser visto e ser ouvido pelos "outros" (VOIROL, 2005). Estamos falando de levar a sério a essencialidade da visibilidade como dispositivo de reconhecimento de diferenças sociais e culturais como parte integrante de políticas de comunicaçáo e cultura circunstanciadas na diversidade cultural como problema que remete a um quadro complexo de justiça social e justiça cultural/simbólica (FRASER, 2005). Quando tratamos da visibilidade como política de reconhecimento, admitimos que isso requer suportes simbólicos, ou seja, infraestrutura mediatizada, como a radiodifusáo/audiovisual, os quais detêm poder de publicização, de reprodução em larga escala de referentes subjetivos de uma expressáo cultural própria ao mundo comum de formas de vida. Isso nos remete, por outro lado, à determinação daquilo que figura na ordem do visível, atingindo grandes públicos, e, também, o que é excluído desse circuito.

Sustentamos que o Brasil, assim como muitos países no mundo, não pode se limitar à adoção de um modelo igualitarista abstrato para garantir a igualdade entre os indivíduos, uma vez que nos encontramos inscritos em um formato de governo democrático pautado, ao menos, normativamente, no sistema de igualdades chamado cidadania ${ }^{2}$, ao qual acrescentamos como reforço o reconhecimento de presenças sociais e culturais distintas. O que chamamos de "crise do modelo republicano" nos remete, na verdade, a um problema democrático fundamental, ou seja, o reconhecimento da desigualdade de relações de poder entre grupos sociais e seus pontos de vistas, o que também revela uma ambivalência recorrente entre ethos igualitarista da cidadania e ethos agonístico da negaçáo de direitos e reconhecimento ao qual as minorias, em geral, experimentam. Embora ocultadas ou minimizadas nos debates públicos

2 A ideia original da cidadania enquanto sistema de igualdade encontra-se, do ponto de vista sociológico, originalmente elaborado por Thomas Humphrey Marshall (1893-198I), que entende o exercício dos direitos de cidadania como remédio eficaz contra o alargamento das desigualdades sociais como marca fundamental das sociedades de classes sociais. (MARSHALL, 1967). 
sobre a ampliação do binômio democracia/cidadania, as questóes de minorias, discriminaçôes e seus desdobramentos assumem centralidade na configuração de problemas públicos, reverberando em distintas lutas por reconhecimento que ganham visibilidade. A esse respeito, vimos em 2005, na França, por exemplo, eclodirem protestos de pessoas majoritariamente oriundas de percursos familiares de migração, nas ruas de Dunkerque à Nice, denunciando o desprezo e "exclusão" social aos quais são expostos, com anuência do Estado e de grande parte da sociedade ${ }^{3}$ ou, no Brasil, em 2013/2014, os episódios dos "rolezinhos" nos shoppings de cidades como São Paulo e Belo Horizonte protagonizados por jovens de periferia, os quais - com seus "maneirismos" em ode à ostentaçáo pelo consumo de marcas - impuseram sua presença em espaços pouco ocupados por pessoas de classes sociais menos abastardas ${ }^{4}$. Sabemos que ambos os episódios somam-se a outros que se tornaram alvos de representaçóes midiáticas que traduziram diferenças socioculturais como reforço à discriminação e formação de um senso comum reducionista acerca das especifidades estéticas e opinativas que circulam na sociedade. Nesses termos, podemos nos interrogar se uma maior visibilidade de expressóes de nossas diferenças conduziria necessariamente a um melhor reconhecimento no sentido de ampliação da solidariedade entre as pessoas?

Não há garantias acerca da efetividade do reconhecimento na esfera das relaçóes sociais ordinárias, mas podemos inferir que o tratamento do reconhecimento enquanto insumo de dispositivos normativos erigidos sob a categoria de diversidade cultural como uma sorte de "agenciadores" da produçáo audiovisual nos países democráticos seria um movimento promissor para informar desde relaçóes primárias (família) às diferentes formas de interaçóes sociais. Nesse sentido, evocar tanto a radiodifusão como o audiovisual como lócus privilegiado de lutas por reconhecimento, portanto, como espaço político, nos remete à assertiva segundo a qual a diversidade cultural, na linguagem dos direitos humanos, não se realiza sem políticas públicas que garantam a sua (re)produção e distribuição, sobretudo, em um cenário onde a cultura, nos

3 Para mais esclarecimentos sobre forma e conteúdo dessas manifestações coletivas na França, vide: Mucchielli e Abderrahim ( 2007).

4 O fenômeno do "rolezinho" é identificado como expressão do chamado "funk ostentação", postulado por jovens das periferias em espaços comerciais, como os shoppings de centros urbanos brasileiros, como estética que remete à apreciação de signos do consumo de luxo (FRANÇA; DORNELAS, 20/4). 
termos de Yúdice (2004), torna-se um recurso ancorado nas lógicas da economia e da política subsumindo à "força perfomativa"s da sua própria utilidade enquanto mercadoria. Torna-se cada vez mais evidente, assim, que a cultura é transversal, afetando e sendo impactada pela intersetorialidade com outras áreas e que a sua "utilidade" está justamente na diversidade de suas expressóes, algo bem compreendido pelo poder estatal e pelo mercado. Nesses termos, pensar em perspectiva convergente os setores de Comunicação e Cultura é acionar a transversalidade institucional e regulatória entre esses dois mundos estimulando sinergias possíveis entre diversos setores, como os de Ciência, Tecnologia e Inovação; o de Educaçáo e Desenvolvimento Social, por exemplo (YÚDICE, 2004, 2015).

Interessa-nos, nessa reflexão, abordar três desenvolvimentos. De início, tratamos da afinidade ética e moral entre as categorias de reconhecimento, cidadania e diversidade cultural sustentando que há uma homologia promissora, no sentido da democratização das comunicaçóes e da cultura, entre liberdade comunicacional e diversidade cultural, enquanto valores fundamentais das sociedades contemporâneas. Em seguida, falamos das perspectivas de impacto da Convençáo de 2005 da Unesco nas atuais políticas culturais e para o audiovisual e a radiodifusão no país, a partir do cotejamento de dados que abarcam o período 2006-2012, compreendendo partes dos governos de Lula e Dilma Rousseff. Apontamos o desenho de um quadro legal para as políticas culturais brasileiras que sinaliza objetivaçóes do princípio de diversidade cultural, destacando as especificidades da adequaçáo tanto do conceito como do dispositivo normativo à realidade brasileira. $\mathrm{Na}$ terceira parte, ao tratarmos da operação dos setores brasileiros da radiodifusão e cinema, olhando para a Convenção, partimos da constatação de um cenário de concentração de meios de comunicação no país, centralizado nas mãos de uma dezena de grupos familiares, religiosos, representantes das elites econômica e política nacionais. Por fim, privilegiamos a crítica à imposição de formas comunicacionais e culturais sistêmicas na esfera pública brasileira em detrimento de modelos mais dialógicos que se referenciam na "eticidade" democrática, no sentido honnethiano, tornando possível vislumbramos a revigoraçáo de nossa cultura

5 Segundo Yúdice (2004, p. 64), poder perfomtivoperformativo refere-se a condicionamentos, as imposições e pressões exercidas pelo campo multidimensional do social e pelas relações institucionais. 
política nos termos do registro ético-moral da diversidade cultural sustentado pela Unesco.

\section{Diversidade Cultural e Reconhecimento: por uma compreensão ética da Convenção da Unesco}

Gostaríamos de introduzir esta exposição com uma breve discussão conceitual acerca da categoria de reconhecimento para pensarmos a concepçáo de diversidade cultural no quadro das políticas públicas para a cultura e comunicação no Brasil sob o impacto da Convenção sobre a Proteção e a Promoção da Diversidade das Expressóes Culturais da Unesco. Esse procedimento se justifica pelo fato de identificarmos no texto da Convençáo duas dimensóes fundamentais que correspondem a princípios de uma eticidade democrática: uma que chamamos de dialógica/comunicacional e outra que identificamos como sistêmica/instrumental/institucional. A primeira dimensão diz respeito à valorizaçáo no documento da unidade do gênero humano e ao mesmo tempo das diferenças culturais entre os países e dentro destes, o que permite suscitar a riqueza do patrimônio da humanidade. $\mathrm{O}$ que corresponderia, em nossa análise, ao cruzamento de modelos de cidadania republicano e comunitarista. A segunda grandeza se refere às recomendaçóes de estabelecimentos de acordos comerciais, políticos e estratégicos entre os países signatários da Convençáa para o trânsito de bens e serviços culturais entre esses e ao reforço da importância de parcerias entre setores público, privado comercial e sociedade civil (não mercado) em função da difusão em escala mundial de produtos culturais locais. O que nos remeteria a um paradigma da cidadania de ordem mais liberal. As duas dimensóes de diversidade cultural evocadas na Convenção dialoga com a noção de cultura como recurso desenvolvida por Yúdice (2004) que enfatiza em seu trabalho as potencialidades da diversidade cultural em se converter em lucro e/ou em justiça social, trazendo renda e reconhecimento para populações, muitas vezes, estigmatizadas em função das distinçóes sociais e culturais que vigoram em uma sociedade.

Entretanto, nesse item do texto, vamos nos ater ao atributo dialógico da Convenção como forma de desenvolver uma formulação que aponte a afinidade eletiva entre diversidade cultural e lutas por reconhecimento na perspectiva tanto da justiça social como da justiça cultural. 
As demandas por reconhecimento decorrem, principalmente, de cinco fenômenos fundamentais: colapso dos apelos coletivos por redistribuição de renda; crescimento das desigualdades sociais; ausência ou pouca tolerância e respeito às diferenças culturais; frágil coesão social e déficit de solidariedade em um determinado meio social. Assim, o problema do reconhecimento de diferenças sociais e culturais passa necessariamente pelo quadro tanto de rupturas sociais como de ocultamento da diversidade cultural de um país ou de uma regiáo. Referimo-nos aqui ao reconhecimento como questáo relativa às concepçóes de políticas distributivas e de direitos culturais, sobretudo, para lidarmos com países marcados por grandes injustiças sociais e simbólicas, como é o caso brasileiro.

O reconhecimento figura como categoria fundamentalmente relacionada às práticas discursivas e manifestaçóes culturais que remetem à representatividade e valorização de expressóes socioculturais de minorias religiosas, segmentos sociais oriundos de culturas de diferentes regióes do país que convivem em localidades onde meios de comunicação, em especial, o rádio e a televisão e o cinema, são consumidos por populaçôes cuja pluralidade da sua configuração social não aparece representada nos conteúdos dessas mídias. Ou seja, os espaços outorgados à expressão cultural das minorias étnicas, religiosas, nacionais de um mesmo país são muitas vezes encerrados em mídias comunitárias ou associativas ou minimizados em função de espaços midiáticos monopolizados por grupos econômicos estabelecidos (LEAL, 2008). Tem-se, então, a invisibilidade de expressóes culturais variadas como privaçáo da vida pública, ou seja, negação de participação na esfera pública imputada a diferentes grupos sociais (ciganos, quilombolas, indígenas, populaçôes rurais e de favelas). Visibilidade aqui coaduna com a noção de participação/aparição pública sem a qual não há plenitude possível de direitos culturais, políticos e civis. Para operacionalizar nossa discussão, os direitos culturais ${ }^{6}$ sáo de relevância significativa por se tratar de uma modalidade de direito náo validado universalmente, dependendo fundamentalmente de sistemas jurídicos sediados em "contextos fortes" de

6 Nos termos de Yúdice (2004, p. 4I): "Os direitos culturais incluem a liberdade de se engajar na atividade cultural, falar a lingua de sua escolha, ensinar sua lingua e cultura a seus filhos, identificar-se com as comunidades culturais de sua escolha, descobrir toda uma variedade de culturas que compreendem 0 patrimônio cultural, adquirir conhecimentos dos direitos humanos, ter uma educação, não deixar representarse sem consentimento [...]". 
reconhecimento das diferenças culturais e opinativas. Em nossas sociedades, há uma dependência imediata entre garantia de direitos e liberdades, horizonte político e cultural e arquitetura institucional para a concretizaçáo do reconhecimento como garantia da estima de si entre nós.

A construção da consideraçáo de si e dos "outros", enquanto portadores de direitos e deveres, passa pelo duplo registro da justiça em sua dimensáo social e cultural, ou seja, nos termos de Honneth (2013), da patologia social e da injustiça. Neste sentido, o reconhecimento deve ser também pensado em conjunto com o paradigma da redistribuição a partir da chave de leitura da economia política, como sustenta Nancy Fraser (2000; , 2005) e das interfaces entre filosofia social e filosofia política (HONNETH, 2013a; , 2013b). Para Fraser a efetividade da justiça social em uma determinada sociedade ou comunidade passa necessariamente pela garantia fundamental de direitos sociais a qualquer cidadáo em paripasso com a essencialidade dos direitos culturais. Fraser enfatiza que o reconhecimento permite a participação na vida social, política, cultural; sendo que a paridade de participação na esfera pública só apenas se torna possível por meio da distribuição de renda. Nesse sentido, fazem-se necessárias políticas para diminuição de desigualdades em favor de minorias; as quais, muitas vezes têm caráter compensatório ou redistributivo em forma de quotas e açóes afirmativas. A autora propóe uma política de reconhecimento e de paridade social baseada nos critérios de redistribuição e reconhecimento das diferenças culturais. A teoria de reconhecimento de Fraser parte do pressuposto de que a injustiça cultural decorre da institucionalizaçáo de modelos sociais de representação, de interpretação e de comunicação em favor da dominação cultural (hegemonia). Ou seja, mais uma vez, a aparição pública das diferenças culturais enquanto vetor de justiça cultural/simbólica não requer apenas acesso à exposição, mas também autorias de versóes e produtos culturais independentes e autônomos da tutela institucional dos meios hegemônicos.

Ao enveredar pela trilha hegeliana, Honneth postula que reconhecer é ação recíproca que começa em cada indivíduo e entre eles, no seio das relaçóes sociais primárias que debutam no âmbito da família, assumindo, depois, outras formas de reconhecimento na esfera das relaçóes formais jurídicas, mediada pelo direito e nas interaçóes ordinárias do cotidiano que demandam 
solidariedade. Em todas essas experiências sociais, para ser considerado é preciso estar visível para ser reconhecido pelo outro; assim, o indivíduo deve se "mediatizar" através de comunicaçóes diretas a partir de relaçóes simbólicas. A questáo é ser reconhecido, ou seja, aceito por todos para fazer parte de uma vitrine social regulada por regras de comportamento segundo códigos morais em uso. As lutas sociais (conflitos), que se ancoram no reconhecimento, emanam de experiências morais, não somente das relações de poder ou de interesses particulares ou coletivos (classe social). Se o sentimento de insatisfação em relação aos eventos sociais é comum a um grupo isso fará nascerem os fundamentos de uma luta social e política que encontrará no apelo ao direito à liberdade individual, em sociedades democráticas, sua forma de expressáo essencial.

Em seu esquema para uma eticidade democrática ${ }^{7}$ em tempos de demandas reprimidas por reconhecimento, Honneth adverte que a base sobre a qual repousam lutas por justiça social somente pode ser compreendida se nos debruçarmos sobre a análise de dados concretos de uma sociedade enquanto encarnaçôes institucionais de valores precisos cuja exigência imanente de realização inspira princípios de justiça específicos oriundos de esferas sociais específicas. (HONNETH, 2015). Isto equivale a dizer que cada esfera constitutiva "[...] da nossa sociedade encarna [...] institucionalmente um aspecto bem determinado de nossa experiência de liberdade individual. A ideia una, moderna, de justiça, é, então, fragmentada em tantos aspectos que existe em nossas sociedades contemporâneas tais esferas institucionalizadas de uma promessa de liberdade eficiente" (HONNETH, 2015, p. 11). A proposta do autor é fazer uma reconstrução normativa de esferas sociais para averiguar até que ponto as concepçóes de liberdade foram institucionalizadas em função da eticidade de práticas e alcançaram concretização social para se ter uma consciência de exigências vindouras de justiça social que estáo inscritas em reivindicaçôes de direitos que ficaram sem resposta ao longo de processos históricos de demandas e não encontraram respaldo em promessas de liberdade institucionalizadas. Ao afirmar que náo se pode

7 Eticidade democrática em Honneth designa conduta de vida correspondente às sociedades democráticas onde a liberdade social (envolvendo as três esferas da eticidade hegeliana - relações pessoais, sociedade civil e Estado) configura a pedra fundamental normativa para realização da liberdade no sentido de "nós" e para reconstrução de quadros institucionais. 
alcançar uma teoria da justiça social sem se referenciar em precondiçóes estruturais de nossas sociedades, Honneth postula que a reproduçáo social de esquemas institucionais a partir dos quais se consolidam as normas repousa sobre um conjunto bem preciso e compartilhado de ideais fundamentais e de "valores forças". A questão é como as esferas sociais participam da salvaguarda e concretização de valores já institucionalizados em um meio social? E, ao mesmo tempo, quais práticas e instituiçóes sociais servem à realização de valores já consagrados institucionalmente? A resposta está justamente na constatação de evidências das condiçóes estruturais da nossa sociedade que permitem esquematizar sobre o modo sistemático de recorrência de práticas costumeiras alicerçadas em instituiçóes morais, ou seja, na liguagemlinguagem hegeliana, qual a eticidade que governa nossas intençóes normativas que regulam nossas vidas. Pensar em uma eticidade democrática, nos termos de Honneth, é (des) construir as tramas históricas que constituem as institutuiçôesinstituiçóes sociais que nos ajudam a formar as nossas concepçôes de mundo, como a mídia, a radiodifusão ou o audiovisual, por exemplo. Trata-se de articular um instrumento metodológico promissor para interpretar a realidade efetiva existente segundo seu potencial para reforçar práticas no seio das quais valores universais poderiam ser concretizados de maneira mais fiel aos ideais universais das sociedades modernas democráticas.

O estabelecimento de um ambiente favorável à solidariedade como dispositivo ético que informa valores e práticas de uma escala individual para a ordem social coletiva encontra respaldo na ideia de liberdade intersubjetiva/ reflexiva apoiada no quadro habermasiano de dialogia ancorado nas estruturas sociais do mundo da vida onde o sujeito se socializa no seio de uma comunidade comunicacional na qual ele aprende a ser destinatário e autor de normas universais. Entretanto, Honneth lembra que para a plausibilidade da ideíaideia de liberdade reflexiva é preciso contar com duas condiçóes fundamentais. De um lado, as instituiçóes que operam na realidade social devem oferecer ocasióes desse objetivo ser alcançado e de outro, a garantia de liberdade individual, sem a qual não teríamos formas institucionais que permitam a aplicação da liberdade intersubjetiva. Ou seja, não há liberdade em termos autolegislativos auto-legislativo ou discursivo discursivos fora da realidade institucional.

Aquilo que torna social esta nova concepção discursiva de liberdade é o fato que ela vislumbra uma instituição bem determinada da realidade social não mais como puro e simples aditivo à liberdade, mas como meio e condição de aplicação dessa liberdade. Desse 
ponto de vista, os sujeitos individuais não podem realizar os atos reflexivos necessários à auto-determinação [sic] sem a condição de interagir socialmente com os outros, tratando sobre o modo da reciprocidade.". (HONNETH, 2015, p. 7I).

Consideramos, inspirados em Honneth, que se os sujeitos dependem de parcerias discursivas para formular sua vontade própria e experimentar a liberdade, necessitando, assim, de estruturas práticas institucionalizadas para fazer avançar o processo de autodeterminaçáo recíproco, as convençóes podem funcionar como bases para edificação de formas mais justas de contemplar a diversidade da nossa existência enquanto seres hermenêuticos portadores de culturas que habitam as sociedades contemporâneas. Assim, é preciso pensar, como diz o autor, na discussão enquanto evento dialógico como uma "instituição particular na multiplicidade de suas manifestações sociais", um meio para o alcance da liberdade reflexiva, consequência do reconhecimento mútuo. Nesse sentido, a justiça traduz-se na oportunidade de participar das instituiçôes de reconhecimento. Este decorre dos valores culturalmente compartilhados nas diferentes esferas sociais agenciando formas de condutas. As exigências de justiça, nesses termos, são encarnaçóes do conjunto de normas que contribuem em distintos contextos de açáo para a realizaçáo adequada de valores prevalecentes. Neste sentido, Honneth (2015, p. 105) observa que a ideia de justiça depende inteiramente de suas relaçóes com valores éticos "porque a exigência de se comportar "justamente" diante do outro é desprovida da menor significação até que ela seja fundada na concepção de bem.” (p. 105). A justiça aqui não é fenômeno transcendental, mas está circunstanciada na simultaneidade entre formaçóes institucionais e realidade social, a qual fornece ao conjunto dos indivíduos as condiçóes para o exercício de sua liberdade individual necessária para perseguir seus objetivos.

Como o reconhecimento, desde Hegel, somente se dá pela mediação institucional que permite interaçóes normativamente reguladas com o outro, o advento de novos dispositivos institucionais com o objetivo de estimular atitudes e modos de comportamento mais apropriados ao sentido de uma eticidade democrática, que resguarda direitos que uns e outros devem se acordar para colocá-los em prática, pode se constituir em modo promissor de alcançarmos uma espécie de um "reconhecimento normativo". Trata-se da introjeção do 
ato de reconhecer o outro como a si próprio enquanto cidadáos pertencentes a um mundo da vida perpassado por muitas vozes e registros culturais; uma orientação ética presente em nossas subjetividades, em nossos estilos e modos de vida, em nossa mentalidade de agentes sociais, agindo, no sentido foucaultiano, sobre as nossas "técnicas de si", facilitando monitoramentos e ajustamentos em prol dessa eticidade democrática. O reconhecimento normativo não seria um fenômeno metafísico, mas estaria duplamente condicionado, em nosso entendimento, a um quadro institucional plausível que favorecesse formas de visibilidade de propriedades diferenciais dos sujeitos individuais de forma vinculativa e intersubjetiva, correspondendo ao que reconhecemos neste texto como diversidade cultural como fenômeno dialógico.

O reconhecimento, como sabemos, está vinculado à publicização do próprio indivíduo (a partir da esfera privada até a exposiçáo pública na vida social, na cena social) ${ }^{8}$. O espaço audiovisual figura como lócus para concretização dessa política da vida em sociedades diferenciadas e diversas como a nossa em que as mídias eletrônicas e digitais são lugares epistêmicos onde se formam e (re) produzem referências simbólicas que atuam em nossas trocas intersubjetivas ordinárias. Os meios audiovisuais se configuram em uma estrutura importante de esfera pública contemporânea, como bem observa Habermas (2007), onde é possível publicizar formas e expressóes de vida, permitindo uma "visibilidade midiatizada"

Devido a tal poder de tornar públicos modos de existência humana diferentes, os meios de comunicação também podem se constituir em veiculadores de modelos unitários e padronizados de vida social e cultural, dando a impressão de que a sociedade é homogênea e consensual, em termos opinativo, ideológico, estético. As lutas por reconhecimento de diferenças sociais e

8 Já para J. Rawls, o processo de reconhecimento se dá a partir das instituições políticas, primeiro e depois as condições são dadas para ser reconhecido chega ao meio familiar. Para Habermas o reconhecimento se dá a partir da experiência da reciprocidade por meio da comunicação racional (interação entre os individuos no espaço social), advindo de um processo moral que é anterior ao conflito, o que leva a constituição de uma identidade cívica decorrente do reconhecimento.

9 Voirol (2005, p. 98) define visibilidade mediatizada como "[...] uma relação entre uma porção do mundo percebida por um mediador, objetivado em suportes (textos, sons, imagens fixas ou móveis) e experimentada por um sujeito a partir de seu olhar próprio, inserido em um universo moral e prático.". 
culturais vêm justamente trazer um elemento importante para pensar o desempenho da indústria cultural contemporânea e seus impactos sobre mudanças sociais alavancadas pelo reconhecimento como processo afetivo, moral e legal (direito) cuja negação tem historicamente desembocado em desgastes sociais. As diferenças entre as pessoas aparecem como distinções humanas constitutivas de um mundo plural, onde as desigualdades sociais não se impóem como processos naturais, mas como fenômenos sociais e morais que podem ser atenuados ou reforçados segundo a atuaçáo de mecanismos reguladores das distinções sociais, como as políticas públicas.

O exercício da diversidade cultural apresenta-se, pois, alinhavado na complexa tarefa de entender que as diferenças devem ser pensadas como condição de originalidade e pluralidade do homem, portanto, como um elogio à condição humana. A experiência com a diversidade exige um olhar que capta o outro na sua opacidade, ou seja, que não tenta impor a ordem do conhecimento completo sobre o outro. (MELO, 20I I, p. 9).

Rever modelos culturais e sociais a partir do binômio reconhecimento/ diversidade cultural permite chegar à crítica aos modelos institucionalizados de interpretação da cultura pela mídia, pautada em interesses unilaterais e hegemônicos. A radiodifusão e o audiovisual vêm sendo alvos de formulação de políticas fundadas em necessidades de minorias de mediar demandas conteudísticas, estéticas e ideológicas de diferentes segmentos da sociedade em prol da coesáo social. Assim, a temática de monopólios e oligopólios públicos e privados sobre o setor da cultura e comunicação em diferentes países tem estado presente nos fóruns internacionais das Naçóes Unidas, em especial, é agenda permanente no âmbito da Unesco porque se trata, fundamentalmente, da proteçáo e promoçáo da pluralidade de modelos interpretativos do mundo.

\section{Diversidade Cultural segundo a Convenção da Unesco: qual suporte para políticas públicas?}

A perspectiva de um novo modelo de comunicação calcado na diversidade de vozes e de culturas é claramente enfatizada no Relatório MacBride (1983) produzido e divulgado no âmbito da Cátedra da Unesco há algumas décadas. Nos anos 1970, esse órgão das Naçôes Unidas organizou um estudo que apontou uma situaçáo generalizada em vários países de concentração dos meios de comunicação e da informação a serviço da exploração, opressão 
popular e da injustiça social. Nesse quadro, as políticas de comunicação estavam mais a serviço de monopólios estatais ou privados do que da democratização da mídia (LEAL, 2009).

Mais recentemente, a Unesco protagonizou o processo de aprovação da Convenção de Promoção e Proteção da Diversidade Cultural por parte seus países membros, entre 2005 e 2007. A Convenção da Unesco se traduz em um instrumento de regulação sobre a diversidade cultural em diferentes países membros que suscita questionamentos sobre a forma de sua aplicação. Jurema Machado (2008) enfatiza que não se trata de uma carta de intençóes ou declaração, nem de uma recomendação, mas de um instrumento jurídico internacional que cria compromissos legais e jurídicos entre seus signatários, sendo a Convenção também evocada como instrumento portador de um "novo universalismo global" (ALVES, 2010).

A Convenção está assentada em quatro pilares essenciais: proteção; promoção da diversidade cultural; soberania dos países para propor e implementar políticas de proteção e promoção da diversidade (o que envolve fomento com recursos públicos) e cooperaçáo internacional. Nesse documento, a diversidade cultural ganha status de direito humano irrefutável e valor universal essencial na produçáo de bens e serviços culturais. $\mathrm{O}$ documento estabelece que ao invés do conceito de "exceção cultural", a diversidade cultural seja categoria fundamental a partir da qual as políticas culturais em seus países membros devem ser reconhecidas e definidas.

Diversidade cultural refere-se à multiplicidade de formas pelas quais as culturas dos grupos e sociedades encontram sua expressão. Tais expressões são transmitidas entre e dentro dos grupos e sociedades. A diversidade cultural se manifesta não apenas nas variadas formas pelas quais se expressa, se enriquece e se transmite o patrimônio cultural da humanidade mediante a variedade das expressões culturais, mas também através dos diversos modos de criação, produção, difusão, distribuição e fruição das expressões culturais, quaisquer que sejam os meios e tecnologias empregados. (UNESCO, 2007, p. 5).

De acordo com Petit (2012), a Unesco, desde sua criação, tem definido a categoria de cultura em função do caráter que suas políticas culturais incorpora. $\mathrm{O}$ autor lembra que o conceito de cultura postulado pela entidade tem se apoiado em outras categorias, segundo distintos momentos políticos de sua atuação no mundo. Tem-se, assim, a ênfase no conceito de identidade 
(no contexto de independência de vários países colonizados e de valorização de diferentes expressóes culturais); em seguida, a cultura aparece vinculada ao poder político para depois se associar aos processos de desenvolvimento.

Mais recentemente, a categoria de cultura se fortalece no âmbito da Unesco vinculando-se à democracia e, portanto, à valorizaçáo das diferenças culturais, o que remete ao foco das suas atuais orientaçóes políticas em direção da chamada diversidade cultural, baseada fortemente sobre o direito cultural como direito universal fundamental do homem que reforça a tolerância em relação às minorias (culturais, étnicas, religiosas, nacionais).

A ênfase das políticas culturais contemporâneas da Unesco na diversidade cultural tem repercutido no quadro das políticas e medidas culturais ${ }^{10}$ de seus países membros em diversos setores estratégicos como os de Comunicaçáo e Cultura. O reflexo da defesa de projetos e açóes que expressem a diversidade de culturas que convivem em um mesmo território tem impactado legislaçóes nacionais que permitem a regulação de atividades comerciais e não comerciais entre prestadores públicos, estatais e privados de serviços de cultura e comunicação, como uma forma de reforçar a solidariedade e a coesão social.

Contudo, como observa Petit (2012), pluralismo - em termos de propriedade e operação de meios de comunicação - não garante automaticamente diversidade de conteúdos objetivadas em produtos culturais ofertados pelas empresas de comunicação. Yúdice (2015) lembra que para contarmos com um quadro efetivo de diversidade cultural, é necessário haver diversidade de expressóes culturais as quais devem se beneficiar de condiçóes materiais para que indivíduos e grupos consigam reproduzir as suas identidades. Isso requer formas institucionais e jurídicas adaptadas ao conteúdo semântico da categoria de diversidade cultural, expressa no documento da Unesco, enquanto norma para operação do princípio ético-democrático do reconhecimento, como sinalizamos antes, a partir de Honneth e Fraser.

A Convenção da Unesco parte justamente da consideração sobre a necessidade de revisão de modelos de se fazer e pensar a cultura e comunicação a

10 "Políticas e medidas culturais" referem-se às políticas e medidas relacionadas à cultura, seja no plano local, regional, nacional ou internacional, que tenham como foco a cultura como tal, ou cuja finalidade seja exercer efeito direto sobre as expressões culturais de individuos, grupos ou sociedades, incluindo a criação, produção, difusão e distribuição de atividades, bens e serviços culturais, e o acesso aos mesmos (UNESCO, 2007, p. 7). 
partir da participação conjunta entre Estado, mercado e sociedade civil (atores sociais) em um movimento em que seria inevitável o enfretamento político e ideológico desses atores em um debate sobre uma nova ordem de produçáo e distribuição de bens e serviços culturais. Mas, diversidade cultural significa fundamentalmente reconhecimento de diferenças culturais e sociais objetivado na veiculação e na apropriação dos meios de produzir bens simbólicos por diferentes grupos sociais não necessariamente alinhados estético-politicamente.

\section{Políticas públicas de cultura e comunicação no Brasil e a Convenção da Unesco: horizonte político-institucional para a diversidade cultural?}

É importante ressaltar, como lembram Duppin (2008, 2015), Melo (2011) e Barros (2008), que o Brasil assumiu papel preponderante no âmbito da Unesco, encarnado na figura do ex-ministro da cultura, Gilberto Gil, na consolidação da Convenção e na aceitação desse instrumento legal por parte de vários países membros das Naçôes Unidas. O Brasil, a despeito da consolidação das diretrizes da Convenção da Unesco de 2005, defendeu, juntamente com a França e o Canadá e contra os Estados Unidos, que as trocas culturais não podiam se sujeitar aos acordos comerciais regulados pela Organizaçáo Mundial do Comércio (OMS), advogando medidas que pudessem fazer frente à concentração cultural, ao aniquilamento das indústrias culturais locais e das expressóes tradicionais (BARROS, 2011). Barros (2011) ainda ressalta que a aceitação da Convenção pela maioria dos estados membros da Unesco teve como grande motivação a necessidade de amenizar os descompassos de trocas culturais entre os países, em especial, no que concerne ao comércio de obras audiovisuais. São, em grande parte, as obras audiovisuais as mais destacadas como meio de interpretação e mediação de diversidades culturais dos países. A situação da sub-representação da diversidade cultural em nossos países se agrava ainda mais, como destaca Albornoz (2015), quando se constata a presença das redes e dispositivos digitais como espaços vitais "[...] para oferta de conteúdos culturais de qualquer tipo" operados olipolisticamente por "novos intermediários digitais" (grandes conglomerados comerciais) que ocupam posiçấo dominante no mercado cultural.

Alicerçado em bases patrimonialistas, o sistema brasileiro de comunicação, em especial, de radiodifusão, está centralizado nas mãos de poucos 
grupos familiares, religiosos, representantes das elites econômica e política deste país. A perspectiva de um sistema de radiodifusão que represente interesses de diferentes públicos, com suas opinióes e gostos estéticos próprios, nem sempre homogêneos ou negociáveis entre si, torna-se cada vez mais vinculada ao reconhecimento da diversidade cultural do país pelos meios de comunicação de largo alcance a partir da força de movimentos sociais e de políticas públicas impostas pelo Estado.

A definição de diversidade cultural nos documentos brasileiros se refere à Convenção que inspira as políticas públicas nacionais assentadas na compreensão da diversidade cultural e sua integração com o desenvolvimento (do ponto de vista econômico), a cidadania e a transformaçáo social. Já para os movimentos sociais no âmbito da cultura e comunicação, a diversidade cultural aparece como diversidade regional para ressaltar justamente que em cada regiấo do país temos uma paisagem social e cultural etnicamente e, muitas vezes, ideologicamente diversificada.

$\mathrm{Na}$ verdade, as diretrizes da Convenção estão presentes fundamentalmente nas ações e nos programas do Ministério da Cultura, em particular o documento se faz presente no Plano Nacional de Cultura (PNC) que orienta as atividades da Secretaria de Cidadania e Diversidade Cultural (SCDC). A noção de diversidade cultural do PNC aponta para a multiplicidade de identidades da população brasileira, assim como da expressão de seus artistas. O PNC é um dos principais instrumentos de planejamento estratégico que organiza, regula e norteia a execução das açóes das partes envolvidas no Sistema Nacional de Cultura que integra a SCDC.

A Secretaria foi instituída em 31 de maio de 2012, pelo Decreto $\mathrm{n}^{\circ}$ 7.743, que aprova a Estrutura Regimental do MinC. As atribuiçóes da secretaria são implementadas por intermédio dos programas Cultura Viva e Brasil Plural. A SCDC tem como missão fortalecer o protagonismo cultural da sociedade brasileira, valorizando as iniciativas culturais de grupos e comunidades de minorias, permitindo a esses o acesso aos bens culturais, principalmente no apoio a projetos de espaços culturais denominados Pontos de Cultura (BRASIL, 2012c).

Mincarelli (2012) enfatiza que os impactos da Convenção nas políticas culturais do Minc implementadas durante o Governo Lula se dáo em termos 
de fomento de projetos e açóes em função da diversidade cultural no Brasil a partir de editais públicos e premiaçóes. As expressóes de distinçóes culturais alvo de tal política são as culturas populares, indígenas, ciganas, quilombolas, ribeirinhas, LGBT, juvenis e da terceira idade. Entre 2004 e 2012, foram fomentados 3.662 Pontos de Cultura em todo o país, dos quais 3.034 já foram conveniados ao Ministério. As atividades realizadas nos pontos são oriundas de uma arquitetura institucional que reúne entes públicos, estatais e privados.

A participação da sociedade civil na gestão das políticas públicas culturais está prevista na Convenção da Unesco e, no caso brasileiro, ela se realiza a partir de três mecanismos centrais de controle público-social sobre as decisóes do Ministério da Cultural, em especial, aquelas que recaem sobre o desempenho do Sistema Nacional de Cultura, são eles: conferências nacionais de cultura; Conselho Nacional de Política Cultural e a Comissão Nacional de Incentivo à Cultura.

O Minc declarou à Unesco em 2012 que, entre os anos de 1990 e 2011, inclusive em período anterior à assinatura da Convenção, foi executor de oito políticas/medidas para fomentar as diferentes etapas de criação, produção, distribuição, difusão e participação/fruição de obras culturais (inclusive audiovisuais) e duas políticas/medidas de cooperaçáo internacional e tratamento preferencial, sendo que todas essas iniciativas se deram em função da proteção e promoção da diversidade de expressóes culturais do Brasil (BRASIL, 2012c).

$\mathrm{Na}$ rubrica referente a açóes do Ministério em favor da proteção às expressóes culturais consideradas ameaçadas no país, o papel da sociedade civil como aliada ao processo de implementaçáo da Convençáo tem sido reforçado pelo Minc, sobretudo em açôes de divulgação dos propósitos do documento da Unesco dentro e fora do Ministério. Entre 2008 e 2009, o Minc realizou cinco seminários e três oficinas de um dia, com o título Diversidade Cultural - entendendo a Convençâo, em capitais brasileiras, visando, sobretudo, a capacitar os públicos de entidades civis e gestores públicos. Ainda no rol de iniciativas governamentais para reforçar a importância da Convenção para o setor, o Ministério da Cultura apoia o Observatório da Diversidade Cultural, uma ONG que tem, dentre seus objetivos, incentivar e realizar pesquisas e práticas inovadoras, desenvolver, orientar e participar de pesquisas e mapeamentos sobre a diversidade cultural brasileira. 
Mas, o Ministério da Cultura admite que precisa avançar no aperfeiçoamento de suas ferramentas de fomento, monitoramento e avaliação das suas políticas, sobretudo, quando levamos em consideração a conversão da cultura em recurso, com relevância política, social e econômica (YÚDICE, 2004, 2015). Entre os inúmeros desafios/dificuldades apresentados pelo órgão, que coaduna com a literatura crítica sobre as políticas culturais brasileiras, temos: falta de dados oriundos de indicadores culturais para melhor informar sobre a paisagem do setor no país; participaçáo ainda pouco satisfatória dos cidadáos na elaboração de políticas culturais; recursos financeiros insuficientes para financiar projetos culturais; acesso restrito da população à produção audiovisual em geral; dificuldades de alguns públicos de lidarem com a linguagem normativa dos editais de fomento a projetos, déficit de formação de recursos humanos para gestáo de projetos dentro e fora do Ministério.

As perspectivas de futuro incluem a ampliação do trabalho intersetorial e a implementação do Plano Nacional "Brasil Criativo", com ações de fomento à economia criativa, e do Sistema Nacional de Informações e Indicadores Culturais, plataforma de governança colaborativa e de transparência pública, que entre outras funções permitirá um monitoramento e avaliação do Plano Nacional de Cultura e dos planos estaduais e municipais. (BRASIL, 20I2c, p. 2).

Um dos grandes desafios apontados por Barros e Júnior (2011) para a promoção de diversidade cultural no país, nos termos da Convenção, é a gestáo cultural dentro do Minc. Os autores discutem as ambiguidades e contradiçôes que permeiam as açôes destinadas a gerir diferenças culturais, sobretudo, porque estamos tratando de alteridade, ou seja, singularidades específicas que caracterizam os indivíduos.

É fato que a gestão cultural permite a passagem do mundo das ideias para as açóes efetivas, mediadas por projetos, mas, além da formação para atuar na execução de programas culturais é igualmente importante pensar a veiculação das expressóes culturais variadas em espaços midiáticos de grande alcance. Dupin (2015) chama a atenção para o déficit de difusão e circulação de bens e serviços culturais produzidos nos Pontos de Cultura e de outras produçóes náo hegemônicas pelo país. Este, sim, é um sério problema em termos de uma ampla visibilidade de obras que retratam a nossa diversidade cultural que se estende ao espaço da radiodifusão e do cinema nacional. 


\section{Impactos da Convenção da Unesco nos setores do audiovisual e da radiodifusão no Brasil?}

Nesta parte, vamos tratar da diversidade cultural, nos termos definidos pela Unesco, pelo Estado brasileiro e pelos movimentos sociais (diversidade regional) nos setores de audiovisual (cinema) e de radiodifusão (televisão aberta e paga) no Brasil. Chamamos atenção que no país a arquitetura regulatória para o setor da radiodifusão aberta e paga envolve mecanismos legais para regular as atividades de infraestrutura (o uso de espectro eletromagnético, a propriedade dos diferentes tipos de mídia, pública, estatal, privada e comunitária, o sistema de concessões de rádio e televisão) como também o desempenho das radiodifusoras (regulação de conteúdos, observando os princípios de liberdade de expressão, proteção de audiências vulneráveis, direito de resposta, para promover o pluralismo e a diversidade, bem como para refrear os discursos que possam ferir os direitos humanos).

\section{Diversidade Cultural na TV aberta brasileira?}

A televisão aberta é, sem dúvida, a mídia eletrônica mais acessada pelos brasileiros. Segundo dados da Pesquisa Nacional por Amostra de Domicílios (PNAD) de 2015, no Brasil, 95,7\% dos domicílios existentes têm aparelho de televisão (BRASIL, 2015). A televisão no país é, inegavelmente, objeto de uma importante prática cultural. A dinâmica do mercado brasileiro de televisão se dá, em grande parte, em função da promissora economia de bens simbólicos proporcionadas pelo alto índice de consumo dos produtos culturais televisionados (telenovelas, filmes, seriados etc.). E é justamente pelo uso social intensivo da TV aberta no país que a sua exploração é questionada pelos movimentos organizados da sociedade civil, devido ao quadro de monopólios que assistimos nesse setor, seguindo a uma tendência constatada em diversos estudos acerca da propriedade dos meios de comunicaçáo na América Latina (ALBORNOZ, 2011; MASTRINI, BECERRA, 2010, GOMIDE; HAJE, 2012).

A função da TV aberta e paga no Brasil é, em especial, a de programação. No país, temos emissoras comerciais e de finalidade cultural e educativa. As primeiras se mantêm a partir de venda de espaços publicitários em sua grade de programação, enquanto as segundas são financiadas por recursos públicos, 
prestação de serviço e publicidade institucional. A televisão aberta no Brasil é regulamentada, fundamentalmente pelo Código Brasileiro de Telecomunicações (1962), modificado por vários decretos e leis. A Constituição Federal de 1988, em seu Capítulo sobre a Comunicação Social, fornece algumas orientaçôes doutrinárias ao setor. Mas, devido à inexistência de uma nova lei de comunicação eletrônica voltada para a Radiodifusão, algumas orientaçóes da nossa Constituiçáo permanecem sem regulamentação, como o incentivo à produção independente e regional, a proibição de monopólios e oligopólios no setor e do equilíbrio entre sistemas público, privado e estatal.

Em termos de regulamentação de conteúdos veiculados pelas emissoras abertas, a legislaçáo vigente determina que o serviço de radiodifusáo serve a finalidades educativas e culturais, e todas as operadoras devem praticar um mínimo de $5 \%$ de conteúdos noticiosos, além da reserva de cinco horas semanais para programas educativos e garantia do direito de resposta a pessoas físicas ou jurídicas que se sentirem prejudicadas por algum programa veiculado pelas operadoras de radiodifusão. Em termos de programação, a cadeia de valor do mercado brasileiro de televisão aberta é considerada bastante verticalizada, isto é, os atores que integram as redes de televisáo participam tanto da produção, programação e distribuição de obras audiovisuais (BRASIL, 2011). A organização da programação é fase bastante estratégica para as emissoras porque é o momento de capitação de recursos com a venda de espaços publicitários que depende do interesse da audiência nos conteúdos exibidos pela rede.

Em termos de produção, as emissoras de televisão aberta no país estão organizadas em redes nacionais, liderada pela chamada "cabeça de rede" que monta a grade de programação que será quase que integralmente exibida pelas afiliadas locais, ou seja, há uma forte repetição regional de conteúdos nacionais produzidos por uma liderança de rede. São $74,4 \%$ de programas exibidos pelas emissoras, locais e nacionais, originados na cabeça de rede nacional, cuja concentração de produção de conteúdos está no eixo Rio de Janeiro e São Paulo (BRASIL, 2011). As produçóes locais mais recorrentes sáo os programas noticiosos e esportivos, já as séries, as telenovelas, os filmes são fornecidos majoritariamente pelas cabeças de rede. Temos 498 emissoras, sendo 295 geradoras de TVs comerciais e 201 educativas e 10.208 retransmissoras vinculados a suas respectivas cabeças de rede, as quais alcançam 95,7\% dos domicílios brasileiros (BRASIL, 2011). 
Os gêneros televisivos mais encontrados na programação das TVs abertas brasileiras, por ordem de presença, são: jornalismo, esporte, programas educativos, telenovelas, minisséries, seriados, cinema, programas de variedades, programas humorísticos, programas infantis, sorteios, premiaçóes, televendas, reality shows, programas religiosos, outros. Dos conteúdos exibidos, em termos de origem geográfica e nacional, temos que $89,4 \%$ dos programas televisivos são concebidos no Brasil (6,6\% vêm dos EUA, 1,2\% do Canadá, $1,1 \%$ México, $0,8 \%$ da Inglaterra, $1,0 \%$ outros), mas a maioria da obras cinematográficas; séries, minisséries são de origem estrangeira (71,7\% provêm dos EUA, 16,5\% do Brasil, 4,8\% Inglaterra, 2,0\% Canadá, 1,8\% Austrália, 1,2\% Dinamarca, 1,1\% México, 0,3\% Argentina, 0,2\% Japão, 0,2\% China, 0,2\% Ucrânia e 0,0\% França) (BRASIL, 2011).

Em 2011, as 10 cabeças de rede do país (TV Globo, SBT, Record, TV Gazeta, Band, MTV, CNT, TV Cultura, TV Brasil, Rede TV) exibiram 82,9\% de programas brasileiros e $17,1 \%$ de programas estrangeiros. Os conteúdos brasileiros veiculados por essas emissoras foram $73,2 \%$ de entretenimento; 99,8\% de informação; $100 \%$ de publicidade; $96,1 \%$ de educação e 99,7\% de outros gêneros (BRASIL, 2011). Essas operadoras de radiodifusáo exibiram em sua programação $13,08 \%$ de longas-metragens brasileiros e $86,92 \%$ longas-metragens estrangeiros. Ao todo, foram 319 filmes brasileiros exibidos na TV aberta brasileira, produzidos, majoritariamente, por empresas consagradas no mercado nacional e internacional. Devemos ressaltar que a Rede Globo não exibe filmes longas ou médias-metragens realizados por produçóes independentes brasileiras.

Nesse quadro de emissoras de TV, a Rede Globo, além de ter o maior núcleo televisivo da América Latina, é a empresa que se destaca como campeá no ranking nacional de participação de audiência em relação ao total de aparelhos de televisão ligados, com o índice de 47,92\% (BRASIL, 2011). Embora a Globo mantenha no país as bases de sua produção cultural de caráter majoritariamente nacional, do ponto de vista de conteúdos não significa que a emissora incorpore a integralidade da diversidade cultural na radiodifusão brasileira. Há no setor uma nítida escassez de combinação entre diversidade temática em função da pluralidade cultural e de combate a estereótipos, preconceitos e tabus sociais e diversidade de fontes de produção desses conteúdos. Os canais abertos comerciais brasileiros, a despeito de operarem no espaço público 
de transmissão de conteúdos, sujeitos à concessão pública, são expoentes do significado mais literal de injustiça cultural expresso por Fraser (2004), uma vez que ocultam cotidianamente os pluralismos interpretativos e a diversidade simbólica característica de nossas culturas. São espaços de invisibilidade e não reconhecimento de nossa diversidade cultural.

A criação da Empresa Brasil de Comunicação (EBC)", em 2008, pode ser mencionada aqui como uma iniciativa governamental que sinalizou a valorização das diferentes expressóes culturais e ideológicas brasileiras em sua programação, nos termos da Convenção. Trata-se de uma empresa pública de radiodifusão que assumiu como compromisso a veiculação das especificidades culturais do país, a partir da transmissão de conteúdos produzidos no âmbito da EBC, das operadoras locais vinculadas a essa rede e de produtores independentes. Mas, ainda precisamos nos apoiar em mais pesquisa sobre as dimensôes discursivas e conteudisticas conteudísticas da produção audiovisual da EBC para confirmamos os pressupostos da sua criação enquanto mídia pública atuando na interface entre universalismo e particularismos culturais.

\section{Diversidade cultural na TV por assinatura brasileira?}

A televisão por assinatura no Brasil ainda não teve seu acesso universalizado, como é o caso da televisão aberta. Ao final de 2011, a penetração da TV paga sobre o total dos domicílios brasileiros com aparelhos de TV era de 20\%. (BRASIL, 2012e) ocorre por meio de quatro tecnologias: Cabo, MMDS (Multipoint Multichannel Distribution System ou Distribuição de Sinais Multiponto Multicanais), DTH (Direct to Home) e TVA (Serviço Especial de Televisão por Assinatura).

O setor de TV por assinatura brasileiro é regido pela Lei 12.485/2011. A nova legislação, válida desde setembro 2011, prevê que os canais de filmes, séries, animaçóes e documentários exibam três horas e 30 minutos por semana, no horário nobre, de conteúdo audiovisual brasileiro e independente, estabelecendo, assim, um sistema de cotas em benefício da produção audiovisual independente nacional.

II É preciso ressaltar que a iniciativa de pensar e discutir publicamente o formato da EBC ficou a cargo do Ministério da Cultura, e não, como se esperava, do Ministério das Comunicações. 
Em 2011, foram exibidas nos canais de TV Paga no país 1.225 obras audiovisuais nacionais (19,5\%). Desse número, 1.183 foram colocadas no ar pelo Canal Brasil, emissora pública de TV, contra 5.056 obras audiovisuais estrangeiras $(80,5 \%)$. Em relação ao tempo de exibição de obras audiovisuais nessa modalidade de serviço, 92,62\% são de produçôes estrangeiras e 7,38\% de conteúdos nacionais. Foram, ao todo, exibidos nesses canais, em relação a conteúdos brasileiros, 74 produçóes seriadas, 18 curtas-metragens, 164 médias- metragens e 97 longas-metragens e no que concerne a produçóes estrangeiras foram 186 obras seriadas, três curtas-metragens, 155 médias-metragens e 4.625 longas-metragens. $\mathrm{Na}$ lista dos filmes longas-smetragens brasileiros mais exibidos na programação da TV por assinatura no país não constam as chamadas produçóes independentes, mas obras realizadas por empresas consagradas no mercado brasileiro de radiodifusão e de audiovisual, como a Empresa Globo Produçóes. (BRASIL, 2012e).

No Brasil atuam 164 prestadoras do serviço de TV paga, as quais estão organizadas em 84 grupos econômicos (multioperadoras). A principal multioperadora desse mercado é a Net Serviços, com capitais das Organizaçóes Globo e da Embratel, que lidera controlando 44\% mercado do serviço no país. Em segundo lugar está a Sky, também formada por capitais das Organizaçóes Globo, detendo 26\% do mercado. Os demais conjuntos de operadoras controlam 30\% desse negócio.

Atuam no mercado brasileiro de TV Paga 41 grupos de empresas programadoras que oferecem 116 canais comerciais de programação. Com exceção da Globosat Programadora Ltda. e de mais cinco pequenas programadoras nacionais (totalizando 16 canais), as demais empresas pertencem a grupos estrangeiros de mídia que atuam em etapas da cadeia de valor desse serviço, sob a perspectiva do mercado mundial, ou seja, pouco atentos às especificidades sociais e culturais do país. (BRASIL, 2011). Nesse mercado, há duas fontes de receitas fundamentais publicidade e comercializaçáo de conteúdos entre canais de programação e operadoras do serviço. Os programas náo seriados (filmes e documentários); esportivos, animaçôes e séries são os conteúdos mais acessados e ofertados pelos canais pagos.

Todas as operadoras de TV a cabo que atuam no país, por imposição legal, têm que de ofertar alguns canais obrigatórios (must-carry), como canais 
legislativos, educativo-cultural, comunitário, universitário. Isso permite certa abertura desse espaço televisivo para produçóes locais não comerciais e independentes no que concerne aos canais universitários e comunitários.

Há um grupo de canais, chamado de sub-premium (Telecine Cult, Canal Brasil e o Cinemax), que veicula obras náo seriadas, documentários e animaçóes brasileiras e postulam que sua programação atende às perspectivas da diversidade cultural por trabalharem com produtos cinematográficos mais seletos, artisticamente mais elaborados, voltados para um público de maior poder aquisitivo e menor audiência. (BRASIL, 2011). Nesse sentido, se confunde-se diversidade cultural com "seletividade" que favorece os chamados conteúdos cult e, assim, não se pode afirmar que esses canais sejam fontes de veiculação das diferentes expressốes culturais brasileiras ou de outros países.

A produção audiovisual nesse setor é também bastante verticalizada em função da atuaçáo de grandes grupos de mídia, em especial, os americanos que acabam por controlar as etapas da cadeia de valor, modelos de negócio e formas de comercialização dos produtos gerados. Esse sistema de produção, programação e distribuição de conteúdos audiovisuais favorece a concentração nas máos dos grandes conglomerados de mídia, gerando barreiras para a comercializaçáo de obras oriundas de pequenas produtoras independentes. (BRASIL, 2012e; 2012b).

A chamada produção independente encontra pouco espaço na grade de programação da televisão paga brasileira. Camargos (2011) lembra que, na televisão por assinatura, há maior presença do conteúdo estrangeiro em relação ao conteúdo nacional e muito baixa incidência da produção audiovisual nacional independente. $\mathrm{Na}$ verdade, o conceito em voga no país acerca da produção audiovisual independente está relacionado à definição de diversidade proposta pela Convenção da Unesco. Vejamos: "O texto da Convenção, ratificado pelo governo brasileiro em 2006, ressalta que a diversidade se manifesta, entre outros, através dos modos de produçáo, difusão, distribuição e fruição das expressôes culturais, quaisquer que sejam os meios e as tecnologias empregadas." (CAMARGOS, 2011, p. 11). No entanto, no setor da televisão de acesso condicionado, a incidência de políticas de comunicação brasileiras amparadas nas orientaçóes da Unesco sobre o que vem a ser cultura e diversidade ainda não correspondem aos preceitos da Convenção. 


\section{Diversidade cultural no Audiovisual brasileiro?}

O setor Audiovisual brasileiro é praticamente viabilizado por meio de fomento via recursos públicos administrados e distribuídos pelo Ministério da Cultura que realizou na última década esforços para o financiamento de obras que reflitam o sentido de diversidade cultural, via reconhecimento de diferenças sociais e culturais, segundo a Convençáo da Unesco. A Secretaria de Audiovisual do Ministério, responsável pelo incentivo de obras audiovisuais brasileiras, mantém cinco tipos de editais para fomentar diferentes produções cinematográficas: Edital de Apoio à Produção de Obras Audiovisuais Cinematográficas, Inéditas, de Ficção, de Baixo Orçamento; Edital de Apoio à Produção de Obras Audiovisuais Inéditas de Curta-Metragem, do Gênero Ficção, Documentário e Animação; Edital de Apoio ao Desenvolvimento de Roteiros Cinematográficos Inéditos, de Ficção para Roteiristas Profissionais; Edital de Apoio ao Desenvolvimento de Roteiros Cinematográficos Inéditos, de Ficção para Roteiristas Estreantes e Edital de Apoio à Produção de Obras Audiovisuais Cinematográficas do Gênero Documental inéditas.

Além dos editais, há mecanismos de fomento que se realizam através de ações e programas específicos, como o Programa Brasil, Som e Imagem, executado pela Secretaria de Audiovisual do Minc que fomentou, entre 2007 e 2011, projetos cinematográficos e audiovisuais brasileiros, a partir de 26 editais, que selecionaram 250 projetos. Foram financiados o desenvolvimento de roteiros cinematográficos e a realização de filmes longas-metragens, curtas-metragens de ficção, documentário ou experimental, curtas de animação, curtas infanto-juvenis. Também foram realizadas no período as iniciativas: DOC TV, Anima TV, Programadora Brasil, DocTV CPLP (2008), FicTV, Programa Setorial de Promoção à Exportaçáo - Brazilian TV Producers, XPTA.LAB e Programa BR Games. Ainda podemos citar o apoio à produção audiovisual independente, principalmente, por meio do Programa Olhar Brasil, que favorece a formação e o aprimoramento de técnicos e realizadores de obras audiovisuais. O Programa é executado pelos Núcleos de Produção Digital, que funcionam atualmente em 13 dos 27 estados brasileiros, os quais consistem em espaços com estrutura humana, física, tecnológica e metodológica aptos a promoverem diversas atividades de formação audiovisual. De 2006 até o presente momento, foram realizadas 29 formaçóes, entre oficinas 
e cursos. Os vídeos produzidos a partir das formações são disponibilizados na página do Ministério.

No quadro de iniciativas civis e cívicas no país de produção audiovisual, realizada a partir da apropriação de tecnologias digitais por diversos segmentos da sociedade (comunidades de minorias), Santana (2012) aponta o fortalecimento da cidadania e uma maior participação de diferentes públicos na elaboração de produtos multimidiáticos que expressam a sua realidade a partir do diálogo constante entre produtores e consumidores de conteúdos audiovisuais. Essa correspondência entre especificidades culturais da vida cotidiana de um determinado grupo social ou até de uma população e conteúdos digitais se torna tecnicamente possível com o acesso ao celular, máquinas fotográficas, computador conectado à internet, download e upload de vídeos em portais da web, mesmo se considerarmos certa restriçáo na distribuiçáo de qualquer material produzido por esses meios.

Em 2011, o Fundo Internacional para a Diversidade Cultural, mantido pela Unesco e criado pela Convenção sobre a Proteção e a Promoção da Diversidade das Expressóes Culturais, de 2005, financiou um projeto brasileiro de audiovisual, Indigenous filmmakers producing children's programming in Brazil, da ONG Vídeos nas Aldeias. O produto financiado foi um Kit com um livro e dois DVDs com seis filmes direcionados às crianças não indígenas sobre especificidades da cultura indígena enquanto conteúdo pedagógico para alunos de escolas públicas do país.

Podemos afirmar que há uma razoável produção independente de obras audiovisuais brasileiras, mas a questão da distribuição e exibição desse material, em especial, entre as emissoras de televisão aberta e paga e nas salas de cinemas de grandes conglomerados de mídia, mesmo com o significativo aumento de espaços de exibição de conteúdos cinematográficos no país, se constitui em entrave para realizaçáo da diversidade cultural no setor.

Segundo dados da Superintendência de Acompanhamento de Mercado, Coordenação de Cinema e Vídeo - CCV da Ancine (Agência Nacional do Cinema), em 2012 a arrecadação das salas de exibição brasileiras atingiu o recorde histórico de $\mathrm{R} \$ 1,6$ bilhão, alta de 12,13\% em relação ao ano anterior. No Brasil existiam em funcionamento, até o final de 2012, 2.515 salas de exibição. Como podemos ver, o nosso problema não está na quantidade de 
espaços de exibição de produções culturais ou na escassez de público, mas na invisibilização das expressóes culturais minoritárias que carecem de políticas de proteção e promoção diante de um sistema que privilegia a produção cultural hegemônica. (DUPIN, 2015; KAUARK, BARROS, 2015).

No ano passado, também se alcançou um patamar recorde de público nos cinemas brasileiros, cerca de 146,4 milhóes de espectadores, diante de uma população de quase 194 milhóes de pessoas. Os títulos nacionais, 83 contra 247 lançamentos estrangeiros, foram vistos por 10,62\% daquele montante de público. Dos cinco títulos brasileiros mais vistos do ano, quatro deles foram co-distribuídos através da parceria Downtown/Paris/Riofilme, ou seja, grandes distribuidores cinematográficos. Dos 20 títulos nacionais mais assistidos pelo público brasileiro, não figura entre eles qualquer obra da chamada "produção independente". Esses dados podem refletir um aumento na distribuiçáo e aceitação da produção cinematográfica nacional, indicando estratégias de distribuição mais arrojadas de ocupação do mercado por parte dos operadores do cinema brasileiro, mas não diz nada sobre o acréscimo da produção audiovisual independente nas salas de cinemas do Brasil.

Na verdade, a concentração geográfica (Rio - -São Paulo) e de grupos de produção e distribuição da produção audiovisual no país é muito grande, como sinalizam Camargos (2011) e Pfeiffer (2009). Há uma forte desigualdade regional em termos de produção, distribuição e recepção, o que já compromete a integralidade do princípio de diversidade cultural no audiovisual brasileiro. Em 2007, como lembra Pfeiffer (2009), dos 296 produçóes cinematográficas brasileiras financiadas pelo Minc, 154 eram provenientes do Rio de janeiro, 100 de Sáo Paulo e 12 de Minas Gerais e o restante vinha de outros estados brasileiros. Este quadro de concentração não mudou.

No quadro das coproduçóes estrangeiras, entre 1997 e 2014, o Programa Ibermedia investiu US\$ 85 milhóes em projetos cinematográficos entre países da chamada Ibero-América. Este programa é avaliado como a mais exitosa iniciativa de integração audiovisual da América Latina em termos de coproduçóes. Mas, o gargalo dessa iniciativa está também no déficit de fomento a fluxos cinematográficos inter e intraregional, ou seja, há escassez de uma espaço audiovisual ibero-americano que contemple a circulaçáo dos filmes produzidos no quadro do Ibermedia. Problema que decorre, em certa 
medida, também, da pouca aproximação entre cinema e televisão no sentido da exibição dessa produção regional nos países membros do Programa. (CANEDO; LOIOLA, 2015).

\section{Considerações finais}

Os desafios de pensar a convivência entre iguais, mas diferentes, em nossas sociedades estratificadas e diferenciadas culturalmente se deparam com as nuances da "conveniência da cultura" como insumo para o desenho de estratégias políticas e econômicas dos Estados-naçóes. A cultura se consagra, cada vez mais, como espaço de lutas simbólicas e de disputas políticas e mercantis. Nesse sentido, quando evocamos o tema do reconhecimento social e cultural lidamos a todo tempo com diferenciaçóes endógenas, em termos de manifestaçóes e práticas culturais, de distintas esferas sociais e com a crítica ao processo hegemônico de produção e distribuição de bens e produtos culturais a partir de modelos de negócio sacramentado pelo mercado mundial. Encontramo-nos, assim, em uma encruzilhada onde a diversidade cultural figura como peculiaridade das sociedades complexas, altamente vantajosa para a indústria cultural aliada ao setor do turismo. Isto se impóe como um problema público quando as demandas por direitos culturais de coletividades não encontram eco em garantias universalizadas para todos os grupos pertencentes a um território nacional.

Nas abordagens acerca das lutas por reconhecimento nas sociedades contemporâneas, nós nos confrontamos, ainda, com o problema de, ao postularmos a diferença, estarmos também reforçando a "guetorização", a separação, os abismos entre diferentes grupos sociais. Na verdade, o reconhecimento decorre da justiça mais do que da realizaçáo de si mesmo. Mas, e no caso em que o reconhecimento é negado ao indivíduo e a identidade do sujeito se forma a partir da negação de seu reconhecimento social e cultural, quando princípios republicanos como a igualdade ou liberais como o mérito náo funcionam? Quando o amor e os princípios morais não são suficientes para garantir o reconhecimento, faz-se necessário o apelo ao direito positivo como forma de provimento da solidariedade social. Desse processo, decorrem, assim, as políticas públicas que asseguram direitos universais e específicos ancorados em princípios superiores comuns que excedem os costumes e a moral de particulares. Nesse sentido, a intervenção do Estado a partir de políticas públicas 
figura como mecanismo legítimo e legal para a garantia de veiculação de conteúdos que expressem interesses e demandas de minorias em uma linguagem que representa a diversidade cultural, étnica, opinativa e territorial, a qual muitas vezes é negligenciada pela indústria da comunicaçáo de largo alcance, como se pode testemunhar no Brasil. Entáo, o remédio recomendado por Honneth (2015) é aliar dados da realidade institucional de uma sociedade ao movimento crítico da sua ordem normativa na perspectiva de uma eticidade democrática que informe cidadanias mais condizentes com a proliferação de lutas por reconhecimento. Isso nos leva a considerar que o advento de um "reconhecimento normativo", enquanto uma pedagogia de si, nos termos que vislumbramos aqui, se viabiliza quando o reconhecimento se torna parte de nossas subjetividades e penetra em nossas referências normativas que nos orientam a agir interagindo com os outros numa em uma dinâmica em que os repertórios de demandas de direitos vão atualizando o nosso rol de cidadanias (liberdades individuais/liberdades reflexivas). Todavia, sabemos que processos de reconhecimento dependem de condiçôes institucionais para se concretizarem e se rotinizarem em funçáo de novas demandas sociais, o que exige, muitas vezes, enfrentamentos entre atores sociais para mudanças na ordem regulatória que rege setores estratégicos com o das Comunicaçóes e da Cultura. Quando mencionamos reconhecimento de diversidade cultural associado a políticas de visibilidade das diferenças em nossas sociedades nos remetemos à essencialidade de arcabouços normativos e legais para sediarem açóes que podem encontrar resistências no mundo sistêmico, mas são fundamentais para se adequarem à semântica cambiante das humanidades no mundo da vida.

A Convenção da Unesco é lastro legal inegavelmente importante para subsidiar políticas públicas de cultura e comunicação de seus países signatários, sobretudo por destacar a diversidade cultural como direito humano fundamental, objeto de intervenção do Estado em termos de formulação e implementação de políticas.

A adoção pelo Brasil, em 2007, da Convenção da Unesco para promoção e proteção da diversidade cultural traz as bases para definição de políticas públicas mais condizentes com as perspectivas dos movimentos nacionais pela democratização da comunicação e da cultura. Mas, é preciso ressaltar que os impactos da Convenção têm recaído de forma mais enfática nas 
políticas culturais brasileiras criadas e implementadas pelo Ministério da Cultura, em especial no setor Audiovisual, apesar do problema da circulação desse tipo de bem.

O Ministério das Comunicaçóes não tem formulado suas políticas em função do espírito doutrinário da Convenção. Suspeitamos que grande parte das dificuldades de realização da Convenção no setor de radiodifusão se deve à falta de interface, em termos de políticas públicas, entre os Ministérios da Cultura, da Comunicação e da Ciência, Tecnologia \& Inovação. Schwartz (2011) observa que a ausência de intersecção entre os três ministérios traz implicaçóes negativas para a diversidade cultural no Brasil, porque acaba reforçando monopólios no setor das Comunicaçóes e fragilizando o acesso mais universalizado dos brasileiros às tecnologias da informação e da comunicação. Segundo o pesquisador, "[...], pelo fato de que no Brasil se mantiveram separadas a política cultural da cultura digital e a política de telecomunicação, o Ministério de Comunicaçóes tornou-se a expressão desse monopólio global e das apropriações desiguais dessas inovações." (SCHWARTZ, 2011, p. 77).

Logo, é fundamental a intersecção entre políticas culturais e políticas de comunicação, sobretudo quando nos localizamos em cenários de concentração de meios de comunicação e indústrias culturais, como é o caso brasileiro. É importante pensarmos que as produçóes culturais representativas da diversidade de manifestaçóes de grupos sociais diferentes não restem encerrados neles próprios, ou seja, que não haja um fortalecimento de "guetos" de recepção desses produtos, mas o alcance mais amplo possível para sua exposiçáo. Como enfatiza Machado (2008, p. 34), “[...] não se pode falar mais em política cultural, muito menos em política de promoção da diversidade, sem ter como item central as políticas para a televisão e a internet.”.

Além da questáo da concentraçáo de propriedade de meios de comunicação, no caso brasileiro, Machado (2008) adverte que as dificuldades em implantar as medidas da Convençáo tendem a impactar de forma diferenciada os setores do audiovisual (cinema) e da radiodifusão (televisão), sobretudo porque o primeiro é quase que totalmente subvencionado por recursos públicos e voltado essencialmente para o mercado interno e o segundo é feito, em grande parte, pela iniciativa privada e além do consumo interno, suas obras são amplamente exportadas, em especial a telenovela. 
As emissoras de TV brasileiras, em especial, a Rede Globo, é grande produtora de conteúdos nacionais; mas, isso não significa conteúdos diversos do ponto de vista de pluralismos culturais e opinativos e muito menos independentes, em relação às grandes produtoras e distribuidoras audiovisuais. $\mathrm{O}$ fato de uma única emissora apresentar, do seu ponto de vista, paisagens sociais e culturais diferentes em seus produtos que dizem respeito à configuração de uma sociedade multicultural não garante a diversidade cultural evocada nos termos da Convenção e dos movimentos sociais.

A diversidade cultural nos produtos culturais brasileiros, em especial aqueles próprios aos setores aqui evocados: TV aberta, TV paga e Audiovisual, encontram, então, alguns fortes obstáculos: concentração da cadeia produtiva por um mesmo grupo de empresas de mídia tanto na radiodifusáo como em relaçáo à produção de obras audiovisuais mais acessadas pelos brasileiros; monopólio nos mercados de TV aberta e de TV paga pelas Organizaçóes Globo; concentração de produção audiovisual, inclusive financiada pelo Estado, na região Sudoeste do país; espaço limitado nas emissoras de TV comerciais e nas salas de cinema para veiculaçáo de produçóes cinematográficas independentes; escassez de recursos humanos e financeiros para realização do potencial de projetos audiovisuais brasileiros propostos por diferentes fontes da sociedade civil brasileira associado ao problema da gestáo cultural dentro do Ministério da Cultura e nas entidades civis proponentes de projetos audiovisuais.

Gostaríamos de enfatizar aqui que o reforço à produçáo independente, oriunda de diferentes fontes, inclusive não comerciais, e sua divulgação mais ampla nos meios de comunicação oficiais, além de dialogar com os propósitos do reconhecimento de diferenças sociais e culturais e, portanto, com a diversidade cultural evocada pela Convenção da Unesco, fortalece o projeto republicano democrático da inclusão social dos "outros" em espaços de visibilidade e de participação cidadã na esfera pública. Essas produções, em geral, seguem modelos e conteúdos náo necessariamente consagrados no mercado, levando, por exemplo, em consideração o olhar, a história, o contexto, o savoir faire das diversas minorias de um país. No caso do Brasil, pensamos fundamentalmente em populaçóes ribeirinhas, quilombolas, indígenas, urbanas (favelas), LGBT. Afinal, como bem observa Bernard (2008, p. 45), a Convençáo deve "tornar-se o que ela é. Ou seja: trata-se de passar de um texto consensual amável e ecumênico - para um projeto dinâmico.”. 
Por fim, destacamos que duas formas de se concretizar a diversidade cultural se sobressaem segundo a leitura que fizemos da Convenção da Unesco enquanto dispositivo potencial de reconhecimento de diferenças sociais e culturais. Ambas estão pautadas na essencialidade de políticas públicas que fomentem a visibilidade dessa diversidade, sendo uma operacionalizada a partir de representaçôes midiáticas feitas por produtores culturais profissionais e a outra forma a partir das representaçóes que os próprios grupos sociais fazem de si próprios. Neste último registro, é expressa uma versão forte da diversidade cultural porque se refere à adoçáo de uma postura ética e epistemológica em respeito às comunidades que representam a diversidade cultural brasileira subsidiada no princípio "nada sobre nós sem nós". Reportarmo-nos à concepçáo da diversidade cultural como uma política de reconhecimento articulada à idéia honnetiana de eticidade democrática que possa promover, ao mesmo tempo, o comum e o particular, apoiando-se no sentido tolstoiano - "Se queres ser universal, fale de seu povoado [..]”. Explorar os caminhos onde se cruzam reconhecimento e diversidade cultural no percurso das políticas de cultura e comunicação no Brasil, sem dúvida, é agenda instigante de pesquisa para lidar com distintas e perversas combinaçóes entre reificaçáo, patologias sociais e injustiças culturais em nossa sociedade.

\section{Referências}

ALBORNOZ, L. Questionamentos em torno da diversidade cultural na Ibero-América. In: BARROS, J. M.; KAUARK, G. (Ed.). Diversidade cultural e desigualdade de trocas: participação, comércio e comunicação. São Paulo: Itaú Cultural; Observatório da Diversidade Cultural, Editora PUCMinas, 2011. p. 101-112.

Diversidade cultural e o campo do audiovisual: novos desafios na era digital. In: MIGUEZ, Paulo P. (Org). Diversidade cultural: políticas, visibilidades midiáticas e redes. Salvador: EDUFBA, 2015. p. 153-172.ALVES, E. P. M. Diversidade cultural, patrimônio cultural material e cultura popular: a Unesco e a construção de um universalismo global. Soc. estado. [online]. 2010, v 25, n. 3, p. 539-560. Disponível em: http://www.scielo.br/scielo. php?script=sci_arttext \&pid=S0102-69922010000300007\&lng=en\&nrm=iso $>$. Acesso em: 12 abr. 2013.

BECERRA, M.; MASTRINI, G. Mídia e indústrias infocomunicacionais na América Latina. Revista Observatório Itaú Cultural, São Paulo, n. 9, p. 86-99, 2010, 9. São Paulo: Itaú Cultural, 2010, pp. 86-99. 
BARROS, J. M. (Ed.). Diversidade cultural: da proteçáo à promoçáo. Belo Horizonte, MG: Autêntica Editora, 2008.

BARROS, J. M; KAUARK, G. (Eds.). Diversidade cultural e desigualdade de trocas: participação, comércio e comunicação. São Paulo: Itaú Cultural, Observatório da Diversidade Cultural, Editora PUC-Minas, 2011.

BERNARD, de F. A. Convenção sobre a Diversidade Cultural espera para ser colocada em prática. In: BARROS, J. M. (Ed.). Diversidade Cultural: da proteção à promoção. Belo Horizonte: Autêntica Editora, 2008. pp. 45-51.

CANEDO, D.; LOIOLA, E. Diversidade cultural no cinema Latino e Iberoamericano: políticas para a integração do espaço audiovisual regional. In: MIGUEZ, Paulo P. (Org.). Diversidade cultural: políticas, visibilidades midiáticas e redes. Salvador: EDUFBA, 2015. p. 173-196.

BRASIL. TV Paga - Mapeamento 2010. Brasília: Ancine, 2011. Disponível em: <http:// www.ancine.gov.br/media/SAM/Estudos/Mapeamento_TvPaga_Publicacao.pdf $>$. Acesso em: 12 abr. 2013.

Dados e estatísticas sobre o mercado de TV por assinatura no Brasil e em países selecionados. Brasília: Ancine, 2012e. Disponível em: http:/www.ancine.gov.br/sites/default/ files/anexos/DadosTVPagav5.pdf>. Acesso em: 12 abr. 2013.

Informe de acompanhamento do mercado de TV Paga: monitoramento da programação 2011. Brasília: Ancine, 2012b. Available atDisponível em: <http://oca.ancine. gov.br/media/SAM/2012/Programacao/informetvpaga2012.pdf>. Acesso em: 12 abr. 2013. . Relatório periódico quadrienal sobre as medidas para proteger e promover a diversidade das expressóes culturais. Brasília: Ministério da Cultura, 2012c.

Famílias Ribeirinhas - Cadastradas. Brasília: Ministério do Desenvolvimento Social (MDS), 2012d. Disponível em: <http://aplicacoes.mds.gov.br/sagi/miv/ miv_pepe.php?nome_banco $=$ mi_cecad $\&$ nome_prog $=\&$ dados_negativos $=\&$ mostra programa $=\&$ codigo $=25 \&$ tabela $=$ ano_pais $\&$ nome_programa $=$ Fam $\% C 3 \%$ ADlias + Ribeirinh

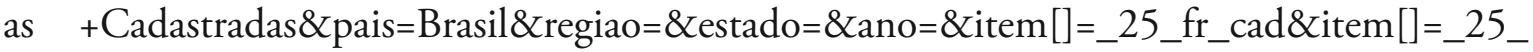
fr_cad_sal_min $\&$ item[] =_25_fr_cad_70_140\&item[] =_25_fr_cad_70\&areas_ especiais $=\&$ areas_especiais_text $=\& \mathrm{idhm}=\&$ populacao $=\% 3 \mathrm{E} \% 3 \mathrm{D} \&$ populacao_valor $=0>$. Acesso em: 14 abr. 2013.

Decreto no 7.743, 31 de maio 2012. Aprova a Estrutura Regimental e o Quadro Demonstrativo dos Cargos em Comissáo e das Funçóes Gratificadas do Ministério da Cultura. 
Diversidade Cultural e Reconhecimento no Quadro de Políticas de Comunicação e Cultura no Brasil: desafios e perspectivas para concretização da Convenção da Unesco de 2005 | Sayonara Leal

Diário Oficial dda Repuública Federativa do Brasil, Brasília, DF, 1 jun. 2012a. Disponível em: <http://www.planalto.gov.br/ccivil_03/_Ato2011-2014/2012/Decreto/D7743.htm>. Acesso em: 12 jan. 2013.

Secretaria de Políticas de Promoção da Igualdade Racial - -SEPPIR/PR. Agência de Cooperação Espanhola para o Desenvolvimento - AECID. Relatório da 2a Missão Técnica à Espanha. Brasília, 2013. Disponível em: http://www.seppir.gov.br/arquivos-pdf/relatorio-da2a-missao-tecnica-a-espanha>. Acesso em: 5 out. 2014.

Censo 2015 mostra as características territoriais dos aglomerados subnormais e suas diferenças das demais áreas das cidades. Instituto Brasileiro de Geografia e Estatística IBGE, 2015. Disponível em: <http://censo2010.ibge.gov.br/noticias-censo busca=1\&id=1\&i dnoticia=2508\&view=noticia $>$. Acesso em: 12 jun. 2013.

Decreto No 7.743, 31 Maio 2012. Disponível em: http://www.planalto.gov.br/ ccivil_03/_Ato2011-2014/2012/Decreto/D7743.htm. Acessado: 12 de janeiro 2013. DUPIN, G. O governo brasileiro e a Diversidade Cultural. In: BARROS, J. M. (Ed.). Diversidade Cultural: da proteção à promoção. Barros, JM (Ed.) Diversidade Cultural: da proteção à promoção. Belo Horizonte: Autêntica Editora, 2008, pp. 36-44.

Dez anos da Convenção da Diversidade cultural: contribuiçóes para um balanço. In: MIGUEZ, Paulo P. (Org.). Diversidade cultural: políticas, visibilidades midiáticas e redes. Salvador: EDUFBA, 2015. p. 15-58.

FRANÇA, V.; DORNELAS, R. No Bonde da Ostentação O que os “rolezinhos" estáo dizendo sobre os valores e a sociabilidade da juventude brasileira?. Revista ECO-Pós, v. 17, n. 3, p. $1-13,2014$.

FRASER, N. Repenser la sphère publique: une contribution a`a la critique de la démocratie telle qu'elle existe réellement -, (extrait de Habermas and the public sphere, sous la direction de Graig Calhoum., Cambridge:, Mit Press, 1992., p. 109-142)., In: Revue Hermès, 31, Paris: CNRS éditions, 2001, p. 129-156.

Qu'est-ce que la justice sociale? Reconnaissance et redistribution. Paris: La Découverte, 2005.

CAMARGOS, C. G. S. de. Produçáo audiovisual independente e televisão: a luta pelo espaço de exibição. 2011. 251 f. Dissertação (Mestrado em Comunicação)-Universidade de Brasília, Brasília, 2011. 
GOMIDE, C; HAJE, L. Brasil: algumas conquistas, grandes desafios. In: LEAL, S. et al (EDS.). Políticas de comunicaçôes. Um estudo comparado: Brasil, Espanha, Estados Unidos, México e Venezuela. Espanha: Comunicación Social Ediciones y Publicaciones, 2012, pp. 32-56.

HABERMAS, J. Três modelos normativos democracia. In: HABERMAS, J. A inclusão do outro - Estudos de Teoria Política. São Paulo: Ediçóes Loiola, 2002, pp. 39-56.

HONNETH, AxelA. Le droit de la liberté: esquisse d'une éthicité démocratique. Paris: Édtions Gallimard, 2015.

Ce que social veut dire. Paris: Gallimard, Tomo I, 2013a.

Ce que social veut dire. Paris: Gallimard, Tomo II, $2013 \mathrm{~b}$.

Luta por reconhecimento: a gramática moral dos conflitos sociais. Sáo Paulo: Editora 34, 2003.

.Visibilité et invisibilité: sur l'épistémologie de la reconnaissance. In: CAILLE, A (edEd.). De la reconnaissance: don, identité et estime de soi. Revue MAUSS, Paris: La Découverte, semestrielle, n. 23, p. 137-151, 2004, no. 23, 2004, pp. 137-151.

Democracia como cooperação reflexiva: John Dewey e a teoria democrática hoje. In: SOUZA, J. (Ed.). SOUZA, Jessé (Ed.) Democracia hoje: novos desafios para a teoria democrática contemporânea. Brasília: Editora da UnB, 2001, pp. 63-92.

LEAL, S. Rádios comunitárias no Brasil e na França: democracia e esfera pública. São Cristóváo (Sergipe): Editora UFS, 2008.

MACHADO, J. Promoçáo e proteção da Diversidade Cultural: o seu atual estágio. In: BARROS, J. M. (Ed.). Diversidade Cultural: da proteção à promoção. Belo Horizonte: Autêntica Editora, 2008, pp. 27-35.

MARSHALL. T. H. MARSHALL. T.H.. Cidadania, classe social e status. Rio de Janeiro: Jorge Zahar, 1967.

MATTERLART, A. Quem tem medo da diversidade cultural. Le Monde Diplomatique (Brasil). Paris (França), 1 oct. 20051 October, 2005. Disponível em: http://www.diplomatique. org.br/print.php?tipo=ac\&id=1303>. Acesso em: 17 abr. 2013.

MELO, T. O mundo misturado: imbricaçôes entre cultura e gestáo cultural. In: BARROS, J. M.; JÚNIOR, J. O. (Eds.). Pensar e agir com a cultura: desafios da gestão cultural. Belo Horizonte: Observatório da Diversidade Cultural, 2011, pp. 6-12. 
Diversidade Cultural e Reconhecimento no Quadro de Politicas de Comunicação e Cultura no Brasil: desafios e perspectivas para concretização da Convenção da Unesco de 2005 | Sayonara Leal

MINCARELLI, M. TMINCARELLI, MT. A influência da Convenção sobre a diversidade cultural no Plano Nacional de Cultura brasileiro. 2012. 61 f. Monografia (Mestrado em Produção Cultural) - Programa de Graduação em Artes e Estudos Culturais, Universidade Federal da Bahia, Salvador, 2012.

MUCCHIELLI, L.; ABDERRAHIM, A-O. Les émeutes de l"automne 2005 dans les banlieues françaises du point de vue des émeutiers. Revue internationale de Psychosociologie, v. 13, n. 2, p. 137-155, 2007, vol. 13, no. 2, 2007, pp. 137-155. Disponível em: <https://www. laurent-mucchielli.org/public/RIP30_Mucchielli_Ait-Omar.pdf>. Acesso em: 14 abr. 2013.

PETIT, B. M. Por un mercado inteligente diversidad cultural mercado y regulacion. Madri: Erasmus Ediciones, 2012.

PFEIFFER, D. A desconcentração da produção audiovisual no brasil: os casos da bahia Bahia e pernambucoPernambuco. Paper apresentado no V ENCONTRO DE ESTUDOS MULTIDISCIPLINARES EM CULTURA - ENECULT, Faculdade de Comunicação/ UFBa, Salvador-Bahia-Brasil, 27-29 maio 2009 Salvador. Anais eletrônicos. Disponível em: http://www.cult.ufba.br/enecult2009/19539-3.pdf>. Acesso em 12 jan. 2013.

RAWLS, J. Théorie de la justice sociale. Paris: Éditions du Seuil, 1997.

SANTANA, F. A. de. Identidade e produção audiovisual: as transformações nas práticas sociopolíticas em comunidades tradicionais. In: III ENCONTRO BAIANO DE ESTUDOS EM CULTURA - EBECULT. Anais eletrônicos.... Cachoeira: UFRB, 2012. Disponível em: http://www.ufrb.edu.br/ebecult/wp-content/uploads/2012/04/Identidade-eprodu\%C3\%A7\%C3\%A3o-audiovisual-.pdf>. Acesso em 14 maio 2013.

SCHWARTZ, G. Diversidade cultural versus determinismo tecnológico no Brasil. In: BARROS, J. M.; KAUARK, G. (Eds.). Diversidade cultural e desigualdade de trocas: participação, comércio e comunicação. São Paulo: Itaú Cultural; Observatório da Diversidade Cultural, Editora PUCMinas, 2011, pp. 71-82.

UNESCO. Um mundo, muitas vozes (Relatório MacBride). Rio de Janeiro: FGV, 1983.

Convençáo sobre a proteção e promoçáo da Diversidade das Expressóes Culturais (Texto oficial ratificado pelo Brasil por meio do Decreto Legislativo 485/2006). Disponível em: http://unesdoc.unesco.org/images/0015/001502/150224por.pdf>. Acesso em 14 abr. 2013.

VOIROL, O. Les luttes pour la visibilité. Esquisse d'une problématique. Réseaux, v.2005/1 (n 129-130), p. 89-121, 2005. 
YÚDICE, GYŨDICE, George. A conveniência da cultura: usos da cultura na era digital. Belo Horizonte: Editora UFMG, 2004.

Os desafios da diversidade cultural no novo milênio. In: MIGUEZ, Paulo P. (Org.).

Diversidade cultural: políticas, visibilidades midiáticas e redes. Salvador: EDUFBA, 2015. p. 59-92.

\section{Cultural diversity and recognition in the communication and culture policies frame in Brazil: challenges and prospects for the implementation of the 2005 Unesco Convention}

\section{Abstract}

This paper discusses the mismatch between the communication and cultural policies regarding broadcasting in Brazil, notably television and audiovisual (movies), with the principle of cultural diversity mentioned in UNESCO'S Convention on the Protection and Promotion of the Diversity of Cultural Expressions of 2005. We start by reflecting on cultural diversity as a built-in problem of the multicultural societies in which demands for recognition operate from the idea of self-esteem and mutual respect as much as from that of social justice, resulting in permanent social struggles in individuals daily lives. Following, we take a glimpse at the problem of cultural diversity in scenarios of broad-range media monopolies, e.g. Brazil's case, where elements of the democratic ethics, such as freedom of expression, find resistance due to the presence of hegemonic cultural model of production and commercialization of culture and communication. In this respect, we advocate that the fulfillment of the democratizing principles of UNESCO's 2005 Convention requires reforms in our legal framework for Communications which must be based on the tripod of citizenship, recognition and cultural diversity. The emergence of a cosmopolitan symbolic space that gives visibility to universal and particular narratives and aesthetic forms that inhabit our cultural diversity depends on institutional support and routinization of the "normative recognition" as a norm within our inter-subjective action in the life-world.

Keywords: Cultural diversity, recognition, communication and cultural policies in Brazil, Unesco Convention

Recebido em: 07/12/2016

Aceito em: 10/02/2017 